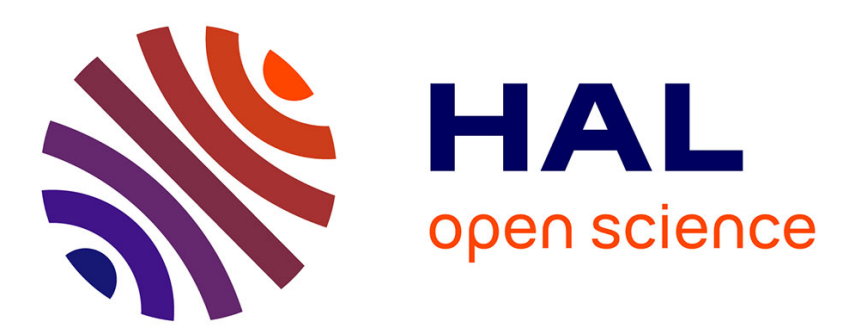

\title{
Immunologic and biochemical effects of intravascular laser blood treatment in patients with gastric precancer
}

\author{
L. Kolomiyets, Ye. Savina, T. Suslova, E. Saprykina
}

\section{To cite this version:}

L. Kolomiyets, Ye. Savina, T. Suslova, E. Saprykina. Immunologic and biochemical effects of intravascular laser blood treatment in patients with gastric precancer. Journal de Physique IV Proceedings, 1994, 04 (C4), pp.C4-231-C4-235. 10.1051/jp4:1994453 . jpa-00252716

\section{HAL Id: jpa-00252716 https://hal.science/jpa-00252716}

Submitted on 1 Jan 1994

HAL is a multi-disciplinary open access archive for the deposit and dissemination of scientific research documents, whether they are published or not. The documents may come from teaching and research institutions in France or abroad, or from public or private research centers.
L'archive ouverte pluridisciplinaire HAL, est destinée au dépôt et à la diffusion de documents scientifiques de niveau recherche, publiés ou non, émanant des établissements d'enseignement et de recherche français ou étrangers, des laboratoires publics ou privés. 


\title{
Immunologic and biochemical effects of intravascular laser blood treatment in patients with gastric precancer
}

\author{
L.A. KOLOMIYETS, Ye.V. SAVINA, T.Ye. SUSLOVA and E.V. SAPRYKINA \\ Cancer Research Institute, Tomsk, Russia
}

\begin{abstract}
Extensive experimental and clinical material accumulated recently in the field of lasertherapy makes it impossible to settle the questions concerning the objective control of treatment efficiency and the selection of optimal radiation regime as well, that is to develop the common theoretical conception. On the other hand the positive clinical results of using the low-energy He-Ne laser allow us to suppose that the laser radiation influences on the universal forms of body reaction. One of the standard responses of organism is stress -reaction. It is non-specific element of disease. The ability of lowenergy $\mathrm{He}-\mathrm{Ne}$ laser radiation to normalize the non-specific reactions of organism predetermines its application in such stress-stipulated diseases as stomach ulcer which is considered to be precancer disease when mucosa dysplasia takes place $(1,2,3)$. It is known that POL intensity plays the important role in the development of different pathologic processes (5). Activation of POL intensity as metabolic realization of stress response can change its physico-chemical potencial and in the case of inertness of anti-radical protection to provoke the cascade mechanism of metabolic and structural changes of cells including gastric mucosa (6). Activation of non-specific
\end{abstract}


immune reaction of organism is of great importance as well (7). At present, the immune control over the tumor growth is considered to be the particular case of immune control over the processes of cell proliferation and differentiation (8).

The aim of our investigation was to study the striking effects of intravascular laser blood radiation (JLBR) with estimation of the state of peroxide oxidation of Iipoids (POL), the state of antioxidant activity (AOA), the state of immunologic status in patients with gastric precancer having good clinical, endoscopic and morphological results following treatment.

\section{Materials and Methods}

Estimation of immunoloqic and biochemical effects of low-energy laser radiation was carried out in patients with stomach precancer. These patients suffered from stomach ulcer with severe epithelium dysplasia. Intravascular laser blood radiation (ILBR) was performed by He-Ne laser radiation with $0,63 \mathrm{mkm}$ wavelength, $5 \mathrm{~mW}$ power at the end of 1 ightquide and $30 \mathrm{~min}$. exposure time for 7-8 deys. Biochemical effects of lasertherapy were estimated by the activity of peroxide oxidation of lipoids.(POL) by the state of antioxidant activity (AOA). Hydroperoxides were defined spectrophotometrically by the typical maximum absorptions in ultraviolet spectrum with 232-234 nm wavelength in lipoid blood extracts. Spontaneous and induced malonic dialdegid was estimated in reaction with 
thiobarbituric acid. AOA was defined by using the stable free radical. Estimation of immune status included the study of humoral and cellular immune factors. The number of $A$ and $G$ immunoglobul ins was defined by Manchini's method of radial immunodiffusion. Circulating immune complexes were defermined by precipitation in polyethyleneglycol (6000). The level of T-lymphocytes in blood was determined by the method of spontaneous rosette-formating with ram erythocytes. Subpopulation composition of $\mathrm{T}$-1ymphocytes was defined according to V.P. Lasovoy et al., 1986.

Results and Discussion

ILBR leaded to the normalization of serum POL level in patients with gastric precancer having good clinical, endoscopic and morphologic effects after treatment. The dynamics of $\mathrm{POL}$ and $\mathrm{AOA}$ changes in that patients allowed two ways of process stabilization to be proposed: 1. Reduction of lipoid peroxidation products owing to the acception of free radicals. This was shown by the reduction of hydroperoxide levels in blood serum from $2,63+0,12$ to $2,29+0,11 \mathrm{mmol} / 1 \quad(p<0,05)$ and spontaneous malonic dialdegide level from $1,21+0,008$ to $0,94+0,003 \mathrm{mmol}$ $11 \mathrm{mg}$ of lipoids $(p<0,05)$. 2. Activation of non-enzymatic link of antiradical protection. This was shown by the reduction of induced malonic dialdegide level from $1,39+0,11$ to $1,03+0,07 \mathrm{mmol} / 1 \mathrm{mg}$ of lipoids $(p<0,05)$ and by serum $A O A$ increase by $32 \%$ as compared to the initial rates. Estimation of immunologic effects by ILBR helped to 
detect the stabilization of immunity humoral factors. The reduction of raised circulating immune complexes by $38 \%$, Ig $G$ from $220,84+11,39$ to $198,48+16,34 \mathrm{ME} / \mathrm{ml}$, Ig A level from $235,29+16,62$ to $211,92+17,39 \mathrm{ME} / \mathrm{ml}$ was observed in patients blood serum following lasertherapy. The reduction of complement activity from $75,76+5,0$ to $67,12+3,9$ was noticed due to the decrease in activation of complement components by immune complexes. The study results of cellular immunity showed the normalization of the number of precursors and low-differentiated T-lymphocytes from $5,8+1,04$ to $2,79+0,5 \%(P<0,05)$ and thymus function from $0,79+0,005$ to $0,93+0,005 \%$ The ratio of $T$-helpers to $T$ -Supressors was normalized as well from $(1,07+0,01$ to $1,29+0,01)$. The analysis of changes of subpopulation composition of immunocompetent cells under the influence of ILBR showed that they depended on the initial rates of cell number, namely: with low initial rates they raised and with elevated initial rates they decreased. There were no significant changes in average rates.

Thus, low-energy He-Ne laser radiation of blood in patients with gastric precancer can be considered as nonspecific modulator of metabolic changes of humoral and cellular immunity. This leads to the increase in antitumoral resistance of organismin these patients. 


\section{REFERENCES}

1. Theses of the conference reports "The action of lowenergy laser radiation on blood". Kiev. 27-29 September, 1989.

2. Theses of reports of the international conference "Laser in medicine". Tashkent. 10-13 October, 1989.

3. Theses of the conference reports " Laser and magnetic therapy in extraordinary clinical investigations. Obninsk. 14-16 June, 1993.

4. Pletnev S. D. Lasers in clinical medicine. $M$, Medicine. 1981, 399 p.

5. Burlakova Ye.B. Physico-chemical principles of autoregulation in clinic. M, 1978.

6. Morosov V.P., Perelygin V.G., Savratsky V.M et al. Peroxide oxidation of lipoids in blood and tissues in patients with gastric ulcer//Clinic medicine. 1992. N 2. P. 75-77.

7. Shabalina V.N., Ivanenco T.V., Skokova T.V. et al. Immunologio and physici-physical laser influence on biological objects // Immunology. 1990. N 6. P. 30-32. 8. Lamakin M.S. Immunologic control. M. 1990. 254p. 